\title{
RESPONSABILIDADE CIVIL DO ESTADO EM DECORRÊNCIA DE ERRO MÉDICO NAS CIRURGIAS ESTÉTICAS REPARADORAS REALIZADA PELO SISTEMA ÚNICO DE SAÚDE
}

\author{
CIVIL LIABILITY OF THE STATE AS A \\ RESULT OF MEDICAL ERROR IN THE \\ AESTHETIC REPARATIONS PERFORMED \\ BY THE SINGLE HEALTH SYSTEM
}

\section{Milena Carolini da Silva ${ }^{1}$}

Resumo: O presente artigo tem como objetivo tratar, a Responsabilidade Civil do Estado em decorrência de erro médico. Cumpre analisar qual é a Responsabilidade a que estão sujeitos o Estado e seus agentes. Inicialmente considera-se o estudo da Responsabilidade Civil, e uma rápida evolução histórica, os tipos de Responsabilidade e os requisitos para o enquadramento na norma legal. Para tanto, analisa-se, brevemente, a jurisprudência acerca da Responsabilidade Civil. Examina-se a aplicabilidade da Responsabilidade em decorrência do erro médico, para, na sequência, estudar a repercussão da dimensão do erro médico estético na esfera pública.
Palavras-chave: Responsabilidade civil do estado. Erro médico. Erro estético. Reparação.

Abstract: The purpose of this article is to address the State's civil liability as a result of medical error. It analyzes the liability to which the State and its agents are subject. A study of civil liability is made, as well as a rapid historical evolution about the types of liability and the requirements for its compliance with the legal standard. For a better understanding of the matter, we study the case law on civil liability, as well as the applicability of liability as a result of medical error, in order to study the repercussion of the dimension of aesthetic medical error

1 Milena Carolini da Silva, Pós-graduanda em Direito Aplicado, pela Fundação Universidade Regional de Blumenau (FURB). Estudante do Módulo Práticas Jurídicas do Curso de Preparação para a Magistratura, da Escola Superior da Magistratura do Estado de Santa Catarina (Esmesc), em Florianópolis. E-mail: milena.carolini@hotmail.com 
practiced by public agents linked to the Unified Health System, the SUS in Brazil.
Keywords: Civil Liability of the State. Medical Error. Aesthetic Error. Repair.

\section{INTRODUÇÃO}

O presente artigo tem como objetivo discorrers obre a Responsabilidade Civil do Estado em decorrência de erro médico no Sistema Público de Saúde. De modo a analisar um tema que possui enorme relevância na atualidade, uma vez que, trata-se da vida humana.

É um tema abordado por administrativistas, civilistas e constitucionalistas que buscam a resposta para a discussão em tela. Depreende-se, assim, que a questão aborda várias áreas do Direito.

Primeiro será estudado a Responsabilidade Civil e uma breve evolução histórica, bem como todos os pressupostos atinentes a ela.

Por fim, tratar-se-á do erro médico, com enfoque no erro estético realizado na esfera pública. Estuda-se a legislação e sua aplicabilidade dos casos pertinentes ao tema, onde demonstra-se a posição do médico e do paciente. Explana-se sobre a conceituação de iatrogenia e sua diferença com relação ao erro médico.

Quanto à metodologia empregada, registra-se que, na fase de investigação foi utilizado o método indutivo, e na fase de tratamento de dados o método cartesiano. Nas diversas fases da pesquisa, foram acionadas as técnicas do referente, da categoria, do conceito operacional e da pesquisa bibliográfica.

\section{RESPONSABILIDADE CIVIL DO ESTADO E SUA EVOLUÇÃO HISTÓRICA}

Devido à sua natureza social, o ser humano, desde o início dos tempos apresentou conflitos ao conviver em sociedade, e, 
por diversas vezes, buscou fazer justiça com as próprias mãos. (GONÇAVES, 1995)

Partindo desse pressuposto, passou a existir o princípio da Lei de Talião, do qual advém a expressão "olho por olho". Urge esclarecer, que as pessoas que conviviam em sociedade, passaram a fazer justiça com as próprias mãos. (VENOSA, 2004)

Com o passar dos tempos, por meio do surgimento da soberania, e de Leis como o Código de Ur-Nammu, derivado do Código de Manu e da Lei das XII Tábuas, as autoridades passaram a impedir queo ofendido fizesse justiça por si só. (GLAGLIANO, 2007)

Assinala-se, que diversas conceituações de Responsabilidade Civil derivam das referidas leis. Obteve-se um entendimento maior no tocante à Responsabilidade Civil no tempo romano, que trouxe a diferença entre reparação e pena. Assim, o Estado tomou para si a função de punição dos indivíduos que infringiram as normas estabelecidas, e foi por meio dessa evolução que surgiu a obrigação deindenizar. (GONÇALVES, 1995)

De acordo com Gonçalves "[...] no direito moderno, a teoria da responsabilidade objetiva apresenta-se sob duas faces: a teoria do risco e a teoria do dano objetivo". (GONÇALVES, 1995, p. 10)

Por consequência, o entendimento referente a Responsabilidade Civil objetiva foi atribuído a sociedade, com o esclarecimento de que cada indivíduo deva pagar pelos seus atos. (STOCO, 2004)

Silvio Rodrigues entende que:

A responsabilidade civil vem definida por Savatier como a obrigação que pode incumbir uma pessoa a reparar o prejuízo causado a outra, por fato próprio, ou por fato de pessoas ou coisas que dela dependam. (RODRIGUES, 2002, p. 10) 
Conforme Carlos Roberto Gonçalves "[...] a responsabilidade civil se assenta, segundo a teoria clássica, em três pressupostos: um dano, a culpa do autor do dano e a relação de causalidade entre o fato culposo e o mesmo dano". (GONÇALVES, 1995)

Por conseguinte, conclui-se que um dos principais pressupostos do dano, é a obrigação de ressarcir. Logo, não deve haver responsabilidade jurídica se não há dano. (ZANONI, 1993)

Tanto no inadimplemento obrigacional, quanto na lesão do direito subjetivo, a lei estabelece ao lesante uma obrigação, a de indenizar a vítima. A reparação do prejuízo decorrido do dano pode ser atendida com a restituição do bem lesado, ou pela liquidação em quantia. (GOMES, 2011)

Assim, a obrigação é um dever jurídico originário, já a responsabilidade é um dever jurídico sucessivo, uma vez que o primeiro foi violado. (GONÇALVES, 1995)

Rui Stoco assevera que "[...] a responsabilidade civil do Estado proveio do direito francês, em que vigia o princípio da irresponsabilidade do funcionário, por motivo de ato lesivo, ocasionado pelo mesmo". (STOCO, 2004, p. 749)

No século XIX o Estado não detinha responsabilidade alguma sobre os atos de seus agentes, desta forma seu vetor encontrava-se no Estado absolutista.(PONTES, 1978)

Valmir Pontes acentua que "[...]o Estado absoluto na Administração Pública não tinha a obrigação de indenizar os prejuízos que seus agentes, nessa qualidade, pudessem causar aos administrados". (PONTES, 1978, p. 291)

Segundo Paulo Nader (NADER, 2016, p. 391-392):

$\mathrm{O}$ instituto da responsabilidade civil, em seu desenvolvimento histórico, registra uma constante mutação, um aperfeiçoamento contínuo, ditado pela crescente consciência da dignidade da pessoa natural, dos deveres inerentes ao Es- 
tado, e de uma sensibilidade maior quanto à perene fórmula do justo: suum cuique tribuere. No passado longínquo, o Estado, além de não assumir a sua condição de mentor da justiça nos casos de danos interindividuais, entregues à reação instintiva das vítimas, não reconhecia a responsabilidade própria. A visão estreita de soberania impedia a compreensão da compatibilidade entre a função de reger a vida jurídica, instituindo leis e aplicando-as, e a condição de titular de obrigações.

A evolução da responsabilidade estatal passou por três principais categorias: a Teoria da Irresponsabilidade, as Teorias Civilistas, que seriam estas os atos de império e de gestão e da Responsabilidade subjetiva, a terceira teoria conhecida como publicista, que enquadra a culpa administrativa e a teoria do risco. (DI PIETRO, 2014)

Destarte que uma mesma conduta pode figurar um ilícito civil e penal, assim, no mesmo momento em que é aplicado ao autor do delito uma sanção penal prevista em lei, pode-se também cominar a vítima o direito de indenização na esfera civil pela mesma conduta. (TARTUCE, 2017)

À vista disso, entende-se que para qualificar um crime, deve-se haver adequação do fato ao tipo penal. Evidencia-se ainda que na esfera cível, a ação ou omissão voluntária origina-se Responsabilidade Civil, conforme dispositivo 186 do atual Código Civil. (TEPEDINO, 2004)

A teoria da culpa, também conhecida como teoria subjetiva, entende, que se não há culpa, não se fala em indenização. Nesse sentido, não se menciona Responsabilidade Civil, pois não houve qualquer dano ou ação danosa. (GOMES, 2011)

Rui Stoco aclara que "[...] o princípio da Responsabilidade Civil, fundou-se essencialmente na doutrina da culpa, abraçada pelo nosso Código Civil de 1916". (STOCO, 1999, p. 76)

Carlos Roberto Gonçalves conclui, no que se refere a teoria 
subjetiva (GONÇALVES, 1995, p. 30):

Diz-se, pois, ser "subjetiva" a responsabilidade quando se esteia na ideia de culpa. A prova da culpa do agente passa a ser pressuposto necessário do dano indenizável. Dentro desta concepção, a responsabilidade do causador do dano somente se configura se agiu com dolo ou culpa.

Com o desenvolvimento social, houveram diversas insatisfações quanto à teoria subjetiva, evidenciada em aspectos abrangendo o cotidiano, que se mostrou incompatível com os tempos mais atuais. Por intermédio do surgimento de diversas situações, ficou demonstrado que a responsabilidade subjetiva não mais supria as necessidades da sociedade, pois, não é sempre que o ofendido obtém êxito em comprovar a existência entre o nexo causal e a lesão. (STOCO, 2004)

Assim sendo, os tribunais notaram que o entendimento de culpa poderia vir a deixar vários casos sem a indenização devida. Mediante esta lacuna, a jurisprudência expandiu o conceito de culpa, onde surgira o conceito de responsabilidade sem culpa ou chamada de teoria do risco. (VENOSA, 2004)

Conforme Carlos Roberto Gonçalves "[...] toda pessoa que exerce alguma atividade cria um risco de dano para terceiros. $\mathrm{E}$ deve ser obrigada a repará-lo ainda que sua conduta seja isenta de culpa." (GONÇALVES, 1995)

Dessa forma, a teoria do risco ou responsabilidade objetiva, deriva da ideia de que o agente, por meio de sua atividade venha a criar algum risco de lesionar terceiros, este tem o dever de repará-lo, mesmo se não há culpa. (RODRIGUES, 2002)

\section{PRESSUPOSTOS DA RESPONSABILIDADE CIVIL}

A Responsabilidade Civil versa na obrigação imposta o lesante, a fim de reparar os danos, desta maneira, deve-se iden- 
tificar os elementos necessários, ou seja, quais os pressupostos que se fazem presentes, para que haja o surgimento da obrigação de indenizar. (NADER, 2016)

Nesse sentido, acentua-se o art. 186 do Código Civil de 2002, que preconiza que "aquele que, por ação ou omissão voluntária, negligência ou imprudência, violar direito e causar dano a outrem, ainda que exclusivamente moral, comete ato ilícito". (BRASIL, 2002)

Logo, distingue-se quatro pressupostos fundamentais da Responsabilidade Civil: ação ou omissão, culpa ou dolo do agente, nexo de causalidade e dano. (FARIAS, 2015)

Para Rui Stoco no tocante a ação ou omissão "[...] o elemento primário de todo ato ilícito é uma conduta humana e voluntária no mundo exterior”. (STOCO, 2004, p.131)

Por consequência, fala-se em Responsabilidade Civil se houve conduta humana que infrinja a lei e que cause danos a alguém, caso determinada conduta não se enquadre neste contexto, não se fala em lesão. Dessa maneira, a ação ou omissão, deve ser estabelecida no primeiro momento da Responsabilidade. (STOCO, 2004)

Importa citar o entendimento de Carlos Roberto Gonçalves (GONÇALVES, 2007, p. 35):

Inicialmente, refere-se a lei a qualquer pessoa que, por ação ou omissão, venha causar dano a outrem. A responsabilidade pode derivar de ato próprio, de ato de terceiro que esteja sob a guarda do agente, e ainda de danos causados por coisas e animais que lhe pertençam.

Consequentemente, o dever de indenizar decorre de um ato, que se torna lesivo, podendo ser uma ação ou omissão do comportamento humano. (GOMES, 2011)

Em relação ao dolo caracteriza-se como a pretensão de um 
ato ilícito da conduta consciente do agente, em que, este almeja o resultado lesivo a vítima. (DIAS, 2006)

Para Carlos Roberto Gonçalves "[...] dolo, portanto, é a violação deliberada, consciente, intencional, do dever jurídico". (GONÇALVES, 1995, p. 35)

No que tange a culpa, o indivíduo não tem a intenção de acarretar dano a alguém, mas em decorrência de sua negligência, imprudência ou imperícia, resulta em uma lesão. (RODRIGUES, 2002)

\section{Esboça Rui Stoco:}

A culpa pode empenhar ação ou omissão e revela-se através de imprudência: comportamento açodado, precipitado, apressado, exagerado ou excessivo; negligência: quando o agente se omite deixa de agir quando deveria fazê-lo e deixa de observar regras subministradas pelo bom senso, que recomendam cuidado, atenção e zelo; e imperícia: a atuação profissional sem o necessário conhecimento técnico ou científico que desqualifica o resultado e conduz ao dano. (STOCO, 2004, p. 132)

Há uma certa dificuldade na definição de culpa, no entanto, não há grandes dificuldades em adequá-la ao caso concreto. Por conseguinte, através da negligência, imprudência e imperícia há um comportamento natural, mas devido à falta de atenção devida, gera-se o resultado lesivo. (VENOSA, 2004)

Urge esclarecer, que a culpa é a conduta imprópria ou equivocada, e pode-se até mesmo dizer voluntária, ainda que o lesante não tenha a intenção de produzi-la. Por sua vez, no dolo, há uma consciência e anseio de alcançar o resultado pretendido. (STOCO, 2004)

O nexo causal é o vínculo entre a ação ou omissão e o dano ocasionado através da conduta do agente, desta forma, trata-se de um dos principais pressupostos da responsabilidade civil. 
(RODRIGUES, 2002)

Neste sentido, é possível notar que, caso o lesado venha a sofrer um dano, mas não em decorrência do comportamento do agente, não há o dever de responsabilidade. (GONÇALVES, 2007)

Desta feita, Rui Stoco articula que "[...] o nexo causal se torna indispensável, sendo fundamental que o dano tenha sido causado pela culpa do sujeito". (STOCO, 2004)

No que diz respeito ao dano, o Código Civil de 2002 aprimorou o art. 186, e sua redação implica em "violar direito e causar dano a outrem". Logo, se o agente causar dano ou violar o direito de alguém, deve este ser responsabilizado. (BRASIL, 2002)

Para existir o dever de responsabilização, a lesão tem que ser provada, posto que decorre de prejuízo. (GONÇALVES, 2007)

Conforme Eduardo Antonio Zanoni “[...] não há nenhuma responsabilidade legal (civil) sem que haja dano". (ZANONI, 1993, p. 2)

Ademais, o dano pode ser moral ou material, qual seja, busca-se reparar moralmente ou financeiramente a lesão sofrida. (ZANONI, 1993)

\section{RESPONSABILIDADE CIVIL DO ESTADO NO BRASIL}

Com o surgimento do Código Civil de 1916 (Lei n. 3.071), não restaram dúvidas acerca da Responsabilidade Civil do Estado, adotando-se a teoria subjetiva expressa em seu art. 15, que dispusera:

As pessoas jurídicas de Direito Público são civilmente responsáveis por atos de seus representantes nessa qualidade causem danos a terceiros, procedendo de modo contrário ao 
direito ou faltando a dever prescrito em lei, salvo o direito regressivo contra os causadores do dano. (BRASIL, 1916)

Nesse seguimento, tinha-se a ideia de que a culpa dos funcionários deveria ser comprovada para que o Estado viesse a responder. Porém, vários autores interpretaram a referida norma como responsabilidade objetiva do Estado, não sendo necessária a comprovação da culpa para o ressarcimento dos danos. (DI PIETRO, 2014)

Dyrlei da Cunha Júnior esboça:

O Código Civil de 1916, inspirado pela Doutrina Civilista da culpa, adotou a Responsabilidade Civil do Estado no seu art. 15, mas de natureza subjetiva (o Estado responde diretamente, mas somente quando o seu agente agiu com dolo ou culpa; o Estado tem assegurado o direito de regresso contra o causador do dano). (CUNHA JÚNIOR, 2015, p.358)

Já com o surgimento da Constituição dos Estados Unidos do Brasil de 1946, que surge após a II Guerra Mundial, de forma que, o mundo pós-guerra reformulou os princípios constitucionais já existentes e baseou-se nos princípios de outros países como a França e a Alemanha, com esta redemocratização do país, trouxe uma nova redação no tocante à Responsabilidade Civil. (BULOS, 2015)

O art. 194 da Constituição dos Estados Unidos do Brasil de 1946, alterou o dispositivo para:

As pessoas jurídicas de direito público interno são civilmente responsáveis pelos danos que os seus funcionários, nessa qualidade, causem a terceiros. Parágrafo único Caber-lhes-á ação regressiva contra os funcionários causadores do dano, quando tiver havido culpa destes. (BRASIL, 1946)

Essa alteração introduziu no sistema brasileiro a teoria da Responsabilidade objetiva do Estado, pela qual o Estado deve 
reparar os danos ocasionados, havendo a presença da culpa ou não. (MELLO, 2016)

Nesse sentido, a Responsabilidade do Estado, provém de que os administrados não possuem o poder de impedir os perigos derivados da ação estatal, logo, estes dependem de uma segurança jurídica. (NADER, 2016)

A Constituição da República Federativa do Brasil de 1988 (CRFB/88) trouxe uma composição distinta das constituições antecedentes, com princípios fundamentais, garantias, organização do Estado, organização dos poderes, defesa do Estado, tributação, ordem econômica e financeira e ordem social. (SILVA, 2006)

Com o fulcro de manter os princípios constituídos até o momento, a CRFB $/ 88$ estabeleceu em seu art. 37 , parágrafo $6^{\circ}$, no que tange a Responsabilidade do Estado:

A administração pública direta e indireta de qualquer dos Poderes da União, dos Estados, do Distrito Federal e dos Municípios obedecerá aos princípios de legalidade, impessoalidade, moralidade, publicidade e eficiência e, também, ao seguinte: $\S 6^{\circ}$ As pessoas jurídicas de direito público e as de direito privado prestadoras de serviços públicos responderão pelos danos que seus agentes, nessa qualidade, causarem a terceiros, assegurado o direito de regresso contra o responsável nos casos de dolo ou culpa. (BRASIL, 1988)

Dessa maneira, além de manter expressamente a Responsabilidade objetiva do Estado, amplia para as pessoas jurídicas de direito privado prestadoras de serviços públicos que respondam pelos danos que seus agentes venham a causar. (CUNHA JÚNIOR, 2015)

Assim, a Responsabilidade objetiva do Estado funda-se por meio do nexo de causalidade entre a ação estatal e o dano. Portanto, incumbe ao Estado o dever de reparar o dano, pois dispensa-se a demonstração da culpa. (CUNHA JÚNIOR, 2015) 


\section{SISTEMA ÚNICO DE SAÚDE}

O Sistema Único de Saúde (SUS) é a denominação para o Sistema Público de Saúde no Brasil, onde atribui aos cidadãos brasileiros o acesso à saúde, que vem desde o atendimento ambulatorial à transplantes de órgãos. (CORDEIRO, 1991)

O SUS foi instituído na CRFB/88, logo após fundamentado na Lei n. 8.080/1990, conhecida como Lei Orgânica da Saúde, que retornou com princípios constitucionais da reforma sanitária dos anos 80 . No mesmo sentido, no ano de 2011 foi promulgado o Decreto n. 7.508, que rege a organização de funcionamento do SUS. (ASENSI, 2010)

A CRFB/88 em seu art. 196 estabelece que:

A saúde é direito de todos e dever do Estado, garantido mediante políticas sociais e econômicas que visem à redução do risco de doença e de outros agravos e ao acesso universal e igualitário às ações e serviços para sua promoção, proteção e recuperação. (BRASIL, 1988)

Por conseguinte, foi por meio do SUS, que todos os cidadãos brasileiros passaram a ter direito à saúde gratuita, que desta forma deve ser financiada através dos recursos derivados do fundo público.

\section{APLICABILIDADE DO CÓDIGO DE PROTEÇÃO E DEFESA DO CONSUMIDOR}

Considera-se que a relação entre médico e paciente se funda no Código de Defesa do Consumidor, pois o Direito médico além de versarem outras áreas tem respaldo na Responsabilidade Civil. Dessa forma, deve-se ressaltar que há diferenças entre a relação consumerista e a relação contratual.

Logo, se haver erro a prestação do serviço médico pode gerar penalidade na área civil, penal e ética. 
De acordo com Silvio de Salvo Venosa:

O tratamento médico é, atualmente, alcançado pelos princípios do Código de Defesa do Consumidor. O paciente coloca-se em posição de consumidor nos termos do artigo $2^{\circ}$ da Lei n. 8.078/90. O médico ou a pessoa jurídica que presta o serviço coloca-se como fornecedor de serviços, de acordo com o artigo $3^{\circ}$. O parágrafo $2^{\circ}$ deste último artigo não deixa dúvidas a respeito, pois apenas os serviços decorrentes de relação trabalhista estarão fora do Código de Defesa do Consumidor: serviço é qualquer atividade de consumo, mediante remuneração. (VENOSA, 2004, p. 110)

Demonstra-se por meio do Código de Defesa do Consumidor que, quando o indivíduo contrai um serviço, sendo o destinatário final, é caracterizado como consumidor. $\mathrm{O}$ fornecedor está descrito no artigo $3^{\circ}$ do Código de Defesa do Consumidor, como "[...] qualquer pessoa física ou jurídica que de maneira profissional ofereça seus produtos ou serviços mediantes remuneração. (GOMES, 2004)

Posto isso, o referido artigo zela pela dignidade, saúde, segurança, proteção dos interesses, melhoria da qualidade de vida, transparência e harmonia das relações de consumo. (COUTO FILHO, 2008)

Nesse diapasão, deve-se atentar que, por não ser qualquer atividade comercial, a saúde merece um cuidado especial, que se necessita ainda, ater no que tange a vulnerabilidade do indivíduo/paciente que precisa dos cuidados do profissional. (FRANÇA, 2014)

$\mathrm{O}$ art. $4^{\circ}$ do Código de Defesa do Consumidor (Lei n. 8.078) dispõe referente a Política Nacional das relações de consumo com o objetivo o atendimento das necessidades dos consumidores, bem como a saúde e segurança dentre outros. (BRASIL, 1990)

Nesse seguimento, Sílvio de Salvo Venosa acrescenta: 
Entre os princípios programáticos estabelecidos no artigo $4^{\circ}$, há o reconhecimento da referida vulnerabilidade do consumidor no mercado de consumo (inciso I) e a coibição e repressão eficientes de todos os abusos praticados no mercado de consumo (inciso VI). (VENOSA, 2004, p. 194)

O Código de Defesa do Consumidor, em seu art. 14 explana:

O fornecedor de serviços responde, independentemente da existência de culpa, pela reparação dos danos causados aos consumidores por defeitos relativos à prestação dos serviços, bem como por informações insuficientes ou inadequadas sobre sua fruição e riscos. (BRASIL, 1990)

O supracitado artigo aplica a Responsabilidade Objetiva aos fornecedores de serviços que podem vir a causar danos ao seu consumidor, ou seja, ao paciente. (MELO, 2008)

No entanto, o parágrafo $4^{\circ}$ do mesmo artigo faz uma ressalva que "[...] a responsabilidade pessoal dos profissionais liberais será apurada mediante a verificação de culpa". (BRASIL, 1990)

Verifica-se, portanto, que há uma exceção à regra, que comina aos profissionais liberais o preceito fundamentado na culpa. Contudo, a doutrina majoritária entende que o referido parágrafo abrange apenas os profissionais liberais que agem em nome próprio, não atingindo a pessoa jurídica a quem está vinculado. (MELO, 2008)

Por esse ângulo, Antônio Ferreira Couto Filho e Alex Pereira de Souza assinalam que "[...] ao analisar com urgência a natureza jurídica da relação médico/ paciente com o objetivo de elevá-la e, portanto, distingui-la da natureza existente entre um comprador de cigarro e o vendedor do bar [...]. (COUTO FILHO, 2008, p. 30)

Logo, a vida não pode ser estimada como um bem de consumo, já que não tem como compará-la com nenhum produto 
comercializado, assim, deve-se tanto o profissional, quanto à quem este estiver vinculado responderem à proporção de sua culpa. Não obstante, deve atentar-se que caso o paciente venha a óbito por problemas de saúde dele mesmo, pois, caso demonstrado que o profissional agiu coerentemente e zelou pela vida do paciente, ao médico não deve ser conferido a responsabilidade pelo óbito. (PANASCO, 1984)

\section{IATROGENIA}

A iatrogenia aborda sobre dano ou doença, material ou psíquico, ocasionado pelo médico ao paciente. Acrescenta-se que qualquer profissional está sujeito a cometer um dano iatrogênico, no entanto a formação médica é essencial para que este tipo de erro não ocorra. (COUTO FILHO, 2008)

Thomas Lathrop Stedman explana iatrogenia como uma “[...] resultante de, ou no exercício de atividades profissionais como médico ou cirurgião. Termo frequente empregado para implicar a auto- sugestão resultante de discussão, do exame ou sugestões do médico". (STEDMAN, 1979, p. 667)

Na visão de Antônio Ferreira Couto Filho e Alex Pereira Souza:

A palavra iatrogenia (iatros: médico; genia: origem) é utilizada para denominar quaisquer doenças ou danos causados a alguém por um ato médico, seja esse ato terapêutico ou cirúrgico. Importante dizer que esses danos englobam inúmeras vertentes, podendo ser consubstanciados em danos psíquicos, farmacológicos ou instrumentais, todos provocados por uma ação médica de óbvia intenção benéfica. É de extrema relevância aduzir que a iatrogenia deve ser encarada por dois aspectos, lato sensue stricto sensu. Em termo mais amplo, isto é, lato sensu, entende-se por iatrogenia o ato médico que causa dano ao paciente, seja esse ato realizado dentro das normas recomendáveis, seja proveniente de uma falha no atuar, o que equivale dizer, de um 
proceder negligente, imprudente ou imperito. [...] A lesão iatrogênica strictu sensu é exatamente aquela causada pelo atuar médico correto. (COUTO FILHO, 2008, p. 31-32)

Depreende-se, portanto, que a iatrogenia pode ser traduzida como alguma atitude médica. Esta prática pode incidir em um resultado negativo da ação médica. Logo, o profissional médico, mesmo que possua ótimos recursos terapêuticos e tecnológicos, ainda sim, está sujeito a cometeriatrogenia.

Existem três espécies de iatrogenia, por primeiro assinala-se as lesões previsíveis, já que o próprio procedimento provoca consequências, já a segunda espécie demonstra uma consequência previsível, no entanto, inesperado, que se pode levar até mesmo a óbito. Por último, a terceira espécie diz respeito as consequências decorrentes de falhas do ser humano durante o exercício da profissão, que podem gerar a Responsabilidade Civil do médico. (MORAES, 1998)

Sublinha-se que erro médico e iatrogenia são conceitos distintos, no entanto,assinala-se que uma lesão considerada como iatrogênica, pode vir a se caracterizar em erro médico. (GONÇALVES, 1998)

É necessário distinguir as diferenças, desta forma, o erro médico de uma maneira clara, que se compreende em a falha do profissional médico durante o exercício de sua profissão, e advém de um inadimplemento de dever contratual ou extracontratual. (MORAES, 1998)

Já a iatrogeniacaracteriza-se como toda atuação médica, seja ela benéfica ou prejudicial. Salienta-se que se caracteriza como um fato possível e indesejável, ou seja, o dano ocasionado ao paciente advindo de atuação médica ou os resultados negativos do tratamento médico indicado. (CERECEDO CORTINA, 1997)

Portanto, a iatrogenia não acarretasempre em Responsabi- 
lidade Civil atribuída ao médico, uma vez que o profissional pode vir a operar de forma tecnicamente adequada, e buscar a melhor opção de cura para o paciente, de modo que, se está diante de caso de exclusão da responsabilidade. (COUTO FILHO, 2008)

\section{RESPONSABILIDADE CIVIL DO MÉDICO NAS CIRURGIAS ESTÉTICAS REPARADORAS}

Entre o paciente e o médico há um contrato de prestação de serviço, que possui as condições imprescindíveis a obrigar o médico (fornecedor) a buscar os recursos necessários e a agir com ética para o bem-estar do paciente (consumidor). (GOMES, 2004)

Já houveram muitas discussões acerca da natureza contratual entre médico e paciente, no entanto, atualmente não restam mais dúvidas acerca do assunto. Desta forma, a responsabilidade contratual poderá ser presumida ou não. (PEREIRA, 2012)

Conforme Carlos Roberto Gonçalves "[...] a obrigação que tais profissionais assumem é uma obrigação de "meio" e não de "resultado". O objeto do contrato médico não é a cura, obrigação de resultados, mas a prestação de cuidados conscienciosos." (GONÇALVES, 2007, p. 239)

A responsabilidade do médico, portanto, é contratual, de modo que não se pode negar que há a formação de um contrato, mesmo tácito, quando o paciente é atendido. (HUMENHUK, 2016)

Ruy Rosado de Aguiar Júnior, citado por Rui Stoco, assevera:

Devemos admitir que a responsabilidade médica não obedece a um sistema unitário. Ela pode ser contratual, deriva- 
da de um contrato estabelecido livremente entre paciente e profissional, a maioria das vezes de forma tácita, e compreende as relações restritas ao âmbito da medicina privada, isto é, do profissional que é livremente escolhido, contratado e pago pelo cliente. Será extracontratual quando, não existindo o contrato, as circunstâncias da vida colocam frente a frente médico e doente, incumbindo aquele o dever de prestar assistência, como acontece no encontro de um ferido em plena via pública, ou na emergência de intervenção em favor de incapaz por idade ou doença mental. (STOCO, 2004, p. 544)

Portanto, cabe ao profissional zelar e respeitar os direitos e a vida do paciente, pois caso ocorra dano, poderá ser implicado a responsabilidade. (GONÇALVES, 2007)

Salienta-se que a Responsabilidade Civil do Médico está fundamentada na teoria subjetiva, que se emprega como elemento constitutivo a culpa lato sensu do agente, o dano e o nexo de causalidade. (DIAS, 2006)

Assim, entende-se que aquele que causar lesão a outrem por prática de ação ou omissão tem o dever de reparar o prejuízo ocasionado, é o que está previsto no art. 927 do Código Civil (Lei n. 10.046). (BRASIL, 2002)

Dessa forma, para pleitear a indenização do dano ocasionado, é necessário que fique demonstrado que a lesão está conexa com o ato comissivo ou omissivo. (BITTAR, 1991)

A relação jurídica na área da cirurgia plástica tem-se uma modalidade diferenciada, diferencia-se a cirurgia estética da reparadora, uma vez que, na estética não há cura de uma doença, mas sim,serve para melhorar a aparência, já a reparadora busca reparar uma deformidade. (HUMENHUK, 2016)

A cirurgia reparadora, visa corrigir esteticamente mutilações, defeitos congênitos ou adquiridos e deformidades, cujo estes defeitos estéticos podem acarretar em prejuízo sentimen- 
tal para o indivíduo. (DIAS, 2006)

Destarte que a cirurgia plástica reparadora pode ser considerada tão imprescindível como qualquer outra cirurgia, no tocante à doença congênita ou adquirida, bem como, ainda quando há um déficit que o tratamento demanda o ato cirúrgico plástico. Ressalta-se que são métodos em que a área da cirurgia plástica busca aperfeiçoar, e restituir a deformidade para o mais normal possível, assim pode-se unir a cirurgia plástica para embelezar e reparar ao mesmo tempo. (DIAS, 2006)

Deve-se destacar exemplos da cirurgia plástica reparadora financiada pelo SUS como defeitos congênitos, consequências de portadores de câncer, mutilações, cirurgia reprodutiva, reprodução assistida, distrofia muscular progressiva, fibrose cística, pacientes com queimaduras, câncer de pele, sequelas em acidentados, cirurgia bariátrica dentre tantas outras. (FRANÇA, 2014)

Já a cirurgia plástica estética não é financiada pelo SUS, a não ser que esteja conexa a cirurgia reparadora, pois a parte estética tem a finalidade de aperfeiçoar a aparência do indivíduo, não necessariamente é algo urgente. (GOMES, 2004)

Assim, pelo fato de o médico cirurgião plástico contrair a obrigação de melhorar a aparência da pessoa, a atividade deste diferencia-se do profissional médico cirurgião reparador,que tende a combater uma doença ou resolver um problema de saúde. Ora, o médico que realiza uma cirurgia reparadora possui a obrigação de atividade meio, que busca todos os recursos necessários para a cura, imputando-lhe a responsabilidade subjetiva, já o cirurgião plástico, que tem a finalidade de embelezar, tem a obrigação de atingir a atividade fim, acarretando-lhe a responsabilidade objetiva. (GIOSTRI, 2002)

O Superior Tribunal de Justiça alega em alguns de seus julgados que se uma mesma cirurgia se tratar de estética e repara- 
dora, a responsabilidade deve ser fracionada, como se vê:

PROCESSO CIVIL E CIVIL. RESPONSABILIDADE CIVIL. MÉDICO. CIRURGIA DE NATUREZA MISTA - ESTÉTICA E REPARADORA. LIMITES. PETIÇÃO INICIAL. PEDIDO. INTERPRETAÇÃO. LIMITES.1. A relação médico-paciente encerra obrigação de meio, e não de resultado, salvo na hipótese de cirurgias estéticas. Precedentes.2. Nas cirurgias de natureza mista - estética e reparadora - , a responsabilidade do médico não pode ser generalizada, devendo ser analisada de forma fracionada, sendo de resultado em relação à sua parcela estética e de meio em relação à sua parcela reparadora. (Superior Tribunal de Justiça. RECURSO ESPECIAL N. 1.097.955)

Assim, é possível compreender que a responsabilidade pode se subdividir e atribuir a parcela para cada tipo de cirurgia.

Denota-se o art. 37 , parágrafo $6^{\circ}$ da $\mathrm{CRFB} / 88$ compreende que:

A administração pública direta e indireta de qualquer dos Poderes da União, dos Estados, do Distrito Federal e dos Municípios obedecerá aos princípios de legalidade, impessoalidade, moralidade, publicidade e eficiência e, também, ao seguinte: $\S 6^{\circ}$ As pessoas jurídicas de direito público e as de direito privado prestadoras de serviços públicos responderão pelos danos que seus agentes, nessa qualidade, causarem a terceiros, assegurado o direito de regresso contra o responsável nos casos de dolo ou culpa. (BRASIL, 1988)

Para tanto, baseia-se que o Estado tem o dever de reparar o dano nos casos de cirurgia estética reparadora financiadas pelo SUS, independente de comprovar a culpa do agente. (SCHEFER, 2003)

\section{Neste sentido, o art. 43 do Código Civil compreende:}

As pessoas jurídicas de direito público interno são civilmente responsáveis por atos dos seus agentes que nessa qualidade causem danos a terceiros, ressalvando direito re- 
gressivo contra os causadores do dano, se houver, por parte destes, culpa ou dolo. (BRASIL, 2020)

Por conseguinte, cita-se o artigo 930 do Código Civil:

No caso do inc. II do art. 188, se o perigo ocorrer por culpa de terceiro, contra este terá o autor do dano ação regressiva para haver a importância que tiver ressarcido ao lesado. Parágrafo único: A mesma ação competirá contra aquele em defesa de quem se causou o dano. (BRASIL, 2002)

À vista disso, entende-se por ação regressiva do Estado, que é o poder a ele conferido de exigir do agente, que provocou o dano, o dever de ressarcir o ente público que arcou com a indenização. (CRETELLA JÚNIOR, 1992)

Partindo desse pressuposto, fundamenta-se também o art. 934 do Código Civil, onde estabelece que "aquele que ressarcir o dano causado por outrem pode reaver o que houver pago daquele por quem pagou [...]". (BRASIL, 2002)

Caso o ato lesivo contenha mais que um autor, estes responderão solidariamente, já se o culpado pelo dano é um indivíduo que não pertenceu ao polo passivo da ação de indenização, contra este, cabe a ação regressiva. (GONÇALVES, 2007)

O entendimento da Jurisprudência do Superior Tribunal de Justiça é pacífico, no que tange a ação regressiva em face do médico público em decorrência de erro médico nas cirurgias reparadores. Entende-se que ao médico cabe a responsabilidade subjetiva, já ao Estado cabe a responsabilidade objetiva, pois este deve indenizar o lesado independente de demonstrar o nexo causal entre a conduta e o dano. (Superior Tribunal de Justiça. RECURSO ESPECIAL N. 1.089.955)

Atenta-se que a vida é o principal bem do ser humano, uma vez que os danos podem tornar-se irreversíveis, foi a partir desta compreensão que foram criadas as Leis neste sentido, para que o lesado tivesse segurança jurídica. (BLOISE, 1998) 
Portanto, a Responsabilidade do médico em geral é caracterizada de maneira subjetiva, ainda,o cirurgião plástico de cirurgia reparadora tem-se a mesma modalidade, já que necessita demonstrar a ação ou omissão, o nexo causal e o dano. Ao passo que, no tocante ao cirurgião plástico na modalidade estética atribui-se a este a obrigação de resultado, que é lhe é atribuída a responsabilidade objetiva. A Responsabilidade do Estado é objetiva, que cabe a este indenizar o lesado, com a possibilidade do direito de ação regressiva contra o agente causador do dano.

\section{CONCLUSÃO}

O presente artigo teve como objeto a análise acerca da Responsabilidade Civil do Estado, a Responsabilidade Civil médica e a sua dimensão.

Para se chegar ao pretendido foi necessária a construção de sete tópicos, cada qual com seus próprios objetivos específicos. O primeiro tópico objetivou-se estudar a Responsabilidade Civil e Responsabilidade Civil do Estado, bem como sua evolução história, seus pressupostos e sua aplicabilidade. No segundo tópico analisou-se os pressupostos da Responsabilidade Civil. O terceiro tópico explanou-se sobre a Responsabilidade Civil no Estado no Brasil. Desenvolveu-se no quarto tópico sobre o Sistema Único de Saúde e um breve histórico. Evidenciou-se no quinto tópico a aplicação do Código de Defesa do Consumidor e a relação entre médico e paciente. No sexto tópico assinalou-se em relação a iatrogenia, sua aplicação e a diferença em relação ao erro médico, e, por fim, no oitavo tópico, investigou-se a Responsabilidade Civil do Estado em decorrência de erro médico nas cirurgias reparadoras financiadas pelo SUS.

Ante ao exposto, no decorrer do artigo, observou-se o im- 
portante instituto da Responsabilidade Civil, a fim de entender a aplicabilidade da Responsabilidade ao Estado e seus agentes.

Dessa forma, a Responsabilidade Civil, está presente no Direito em diferentes áreas profissionais, sendo desta forma imprescindível sua abrangência no campo da saúde.

Portanto conclui-se, que a Responsabilidade Civil do Estado é de suma importância, uma vez que o lesado tem o Direito de ser indenizado em face do dano ocasionado pelo agente público, pois o maior bem jurídico no Direito Pátrio é a vida, considerada como um direito fundamental, devendo ser resguardada e preservada.

\section{REFERÊNCIAS}

AGUIAR JÚNIOR, Ruy Rosado de. Responsabilidade civil do médico. Belo Horizonte. Del Rey, 2000.

ASENSI, Felipe. Indo além da judicialização: o ministério público e a saúde no Brasil. Rio de Janeiro. Escola de Direito do Rio de Janeiro da Fundação Getúlio Vargas, Centro de Justiça e Sociedade, 2010.

BITTAR, Carlos Alberto. Responsabilidade civil médica, odontológica e hospitalar. São Paulo: Saraiva, 1991.

BLOISE, Walter. A responsabilidade civil e o dano médico, legislação, jurisprudência, seguros e o dano médico. Rio de Janeiro: Forense, 1998.

BRASIL. Constituição da República Federativa do Brasil (1988). Disponível em: http://www.planalto.gov.br/ccivil_03/constituicao/constituicao.htm. Acesso em: 20 abr. 2019.

BRASIL. Constituição dos Estados Unidos do Brasil de 18 de setembro de 1946. Disponível em: http://www.planalto.gov.br/ccivil_03/constituicao/constituicao46.htm. Acesso em: 20 abr. 2019.

BRASIL. Lei n. 3.071, de 1 de janeiro de 1916. Disponível em: http:/www.planalto. gov.br/ccivil_03/leis/L3071.htm. Acesso em: 21 abr. 2019.

BRASIL. Lei n. 10.406, de 10 de janeiro de 2002. Disponível em http://www.planalto.gov.br/ccivil_03/leis/2002/L10406.htm. Acesso em: 21 abr. 2019.

BRASIL. Superior Tribunal de Justiça. Recurso Especial n. 1.089.955, do Rio de Janeiro. Relatora: Ministra Denise Arruda. Brasília. Julgado em 3 de novembro de 2009. Disponível em: https://stj.jusbrasil.com.br/jurisprudencia/6165906/recurso-especial-resp-1089955-rj-2008-0205464-4/inteiro-teor-12302690?ref=juris-tabs. Acesso em: 27 abr. 2019. 
BRASIL. Superior Tribunal de Justiça. Recurso Especial n. 1.097.955 de Minas Gerais. Relatora MINISTRA NANCY ANDRIGHI Julgado em 27 de setembro de 2011. Disponível em: https:/ww2.stj.jus.br/processo/revista/documento/mediado/?componente $=$ ATC\&sequencial $=17944998 \&$ num_registro $=200802398694 \&$ data $=20111003 \&$ tipo $=5 \&$ formato=PDF. Acesso em: 27 a $\bar{b}$. 2019.

BULOS, Uadi Lammêgo. Curso de direito constitucional. 9. ed. São Paulo. Saraiva, 2015.

CAVALIERI FILHO, Sérgio. Programa de responsabilidade civil. 10. ed. São Paulo. Atlas, 2012.

CERECEDO CORTINA, Vicente. Iatrogenia y erro médico. Revista Médica del Hospital General de México, v. 60, n. 2, abr./jun. 1997.

CORDEIRO, Hesio. Sistema único de saúde. Rio de Janeiro: Ayuri Editorial, 1991.

COUTO FILHO, Antônio Ferreira; SOUZA, Alex Pereira. Responsabilidade civil médica e hospitalar. 2. ed. Rio de Janeiro: Editora Lumen Juris, 2008.

CRETELLA JÚNIOR, José. Comentários à Constituição Brasileira de 1988. 2. ed. Rio de Janeiro: Forense Universitária, 1992.

CUNHA JÚNIOR, Dirley. Curso de direito administrativo. 14. ed. Salvador: Editora Juspodivm, 2015.

DI PIETRO, Maria Sylvia Zanella. Direito administrativo. 27. ed. São Paulo: Atlas, 2014.

DIAS, José de Aguiar. Da responsabilidade civil. 11. ed. Rio de Janeiro: Renovar. 2006.

FARIAS, Cristiano Chaves de. Curso de direito civil: responsabilidade civil. 2. ed. São Paulo: Atlas, 2015.

FRANÇA, Genival Veloso. Direito médico. 12. ed. Rio de Janeiro: Forense, 2014.

GAGLIANO, Pablo Stolze. Novo curso de direito civil, volume III: responsabilidade civil. 5. ed. São Paulo: Saraiva, 2007.

GIOSTRI, Hildegard Taggesell. Responsabilidade médica. 1. ed. Curitiba: Pensamento Jurídico, 2002.

GOMES, Orlando. Responsabilidade civil. Rio de Janeiro: Forense, 2011.

GOMES, Rui Kleber Costa. Responsabilidade civil do médico no código de defesa do consumidor. São Paulo: Editora Pillares, 2004.

GONÇALVES, Carlos Roberto. Direito civil brasileiro, volume IV: responsabilidade civil. 2. ed. São Paulo: Saraiva, 2007.

GONÇALVES, Carlos Roberto. Responsabilidade civil. São Paulo: Saraiva, 1995.

HUMENHUK, Hewerstton. Responsabilidade civil do estado constitucional por omissão e efetividade dos direitos fundamentais. Porto Alegre: Livraria do Advogado Editora, 2016.

MELLO, Celso Antônio Bandeira de. Curso de direito administrativo. 33. ed. São Paulo: Malheiros, 2016. 
MELO, Nehemias Domingos de. Responsabilidade civil por erro médico doutrina e jurisprudência. São Paulo: Atlas, 2008.

MORAES, Irany Novah. Erro médico e a lei. 4. ed. São Paulo: LEJUS, 1998.

NADER, Paulo. Curso de direito civil: responsabilidade civil. 6. ed. Rio de Janeiro: Forense, 2016. v. 7.

PANASCO, Wanderby Lacerda. A responsabilidade civil, penal e ética dos médicos. 2. ed. Rio de Janeiro: Forense, 1984.

PEREIRA, André Gonçalo Dias. Direitos dos pacientes e responsabilidade médica. Dissertação de Doutoramento em Ciências Jurídico- Civilistas. Faculdade de Direito da Universidade de Coimbra. Coimbra, dezembro de 2012.

PONTES, Valmir. Programa de direito administrativo. 5. ed. São Paulo: Sugestões Literárias, 1978.

RODRIGUES, Silvio. Direito civil. São Paulo: Saraiva, 2002.

SCHAEFER, Fernanda. Responsabilidade civil do médico \& erro de diagnóstico. Curitiba: Juruá Editora, 2002.

SILVA, José Afonso. Curso de direito constitucional positivo. 26. ed. São Paulo: Malheiros Editores, 2006.

STEDMAN, Thomas Lathrop. Medical dictionary. 23. ed. Rio de Janeiro: Editora Guanabara Koogan S.A, 1979.

STOCO, Rui. Responsabilidade civil e sua interpretação jurisprudencial: doutrina e jurisprudência. 4. ed. São Paulo: Editora Revista dos Tribunais, 1999.

STOCO, Rui. Tratado de responsabilidade civil. 6. ed. São Paulo: Editora Revista dos Tribunais, 2004.

TARTUCE, Flávio. Manual de direito civil. 7. ed. São Paulo: Método, 2017.

TEPEDINO, Gustavo. Temas de direito civil. 3. ed. Rio de Janeiro: Renovar, 2004.

VENOSA, Sílvio de Salvo. Direito civil: responsabilidade civil. 4. ed. São Paulo: Atlas, 2004.

ZANNONI, Eduardo A. El daño em la responsabilidad civil. 2. ed. Buenos Aires: Editorial Astrea, 1993.

Recebido em: 30/04/2019

Aprovado em: 26/06/2019 